\title{
Evaluation on the Implementation of the COIS Values on the Teachers of Yayasan Penyelenggaraan Ilahi Indonesia, Semarang
}

\author{
Murwati \\ Soegijapranata Catholic University \\ priscadp@gmail.com \\ Agatha Ferijani \\ Soegijapranata Catholic University \\ priscadp@gmail.com
}

\begin{abstract}
Strong personal traits such as reliable, discipline, devoted believer, high responsibility, willing to sacrifice, and put others needs above his/her own needs, are the personal traits that can build a prosperous society and a more developed country. It also can be said that the quality of someone is not merely measured from IQ (intelligence), but also from EQ (the growing traits). The real education must cover the formation of the whole humanity. The important component of an education institution is teachers. Thus, Yayasan Penyelenggaraan Ilahi Indonesia (YPII) with their vision and missions has formulated some traits (smart, authentic, faith to the Divine's courtesy, and solider or COIS) that must be embraced by the teachers of YPII in order to be able to form good characters of the students thoroughly. This is the reason for evaluation of the implementation of the COIS values on the teachers of YPII. The research used qualitative approach using Focus Group Discussion (FGD) to gather data. Further evaluation on the implementation of the COIS values was to explore the factors supported or obstructed the implementation of COIS values. The research concluded that the implementation of COIS values in the teachers of YPII Semarang is not good. The reason is lack of continuous guidance and coaching. Teacher awareness on their role as a role model for students develops.
\end{abstract}

Keywords: character education, evaluation, exploration, COIS values

\section{INTRODUCTION}

A developed country is indicated by its people who have strong personal traits. The traits such as honest, discipline, faithful, responsible, willing to sacrify, and put public needs above personal ones can contribute in building a wealthy society and in developing the country. True education must take role in building whole personal of human beings. A smart person who does not have good traits may not bring any benefits for him/herself but also may bring harmful for others (Nugroho, 2016). Goleman (in Dryden \& Vos, 2000) who emphasized this in his research discovered that a person's quality of success is not only based on his/her IQ but 
also on EQ or traits arising from the inside of the person. IQ contributes only $20 \%$ to a person's success and emotional factor or EQ takes the $80 \%$ (Dryden \& Vos, 2000, p.140). It can be said that quality of an individual can be measured not only from IQ (intellegence) but also from EQ (growing traits).

Teacher is an important component in an education institution. Yayasan Penyelenggaraan Ilahi Indonesia (YPII) in its vision and missions formulates traits for their teachers based on values of smartness, authenticity, faith to the Divine's courtesy, and solidarity (in Indonesian, it is abbreviated by COIS - cerdas, otentik, iman, and solider). These values must be embraced by the teachers for them to be able to build students' traits wholly. It is thus considerably important to evaluate the implementation of the COIS values on the teachers of Yayasan Penyelenggaraan Ilahi Indonesia, Semarang.

As stated in the Law of National Education System (Sistem Pendidikan Nasional or SISDIKNAS) Number 20 Year 2003 article 1, the goals of the education in Indonesia is concious and planned efforts to create environment for study and learning process that enable students to actively develop their personal potencies in terms of spiritual religious strength, self-control, personality, intellegence, high morality, and skills needed by society, nation, and country.

National education system is an integrated educational components to achieve the goals of national education. The educational component are students, education staff, and teachers. It is stated in article 3 that the goals of the national education are to develop potencies of students to be individuals who are faithful and God-fearing, have high morality, are healthy, educated, skillful, creative, independent, and democratic and responsible citizens. They are also to develop potencies of teachers to be the ones who are educated, God-fearing, healthy, skilfull, creative, independent, and democratic and responsible citizens (President of Republic of Indonesia, 2003). 
The Book of Church Canonic Law in particular the internal law of Catholic Church canon 795 emphasizes that true education must cover development of whole humans personality that put attention on the final aim of a human and welfare of the community in general. Thus, children and their tougths must be cultivated in a way that can grow their physical talents, moral, and intellectual in harmony so that they can be more responsible, use their freedom correctly, and participate actively in the community life (Konverensi Waligereja Indonesia, 2016: 243). Development of character education must be prioritized for quality of human resources to grow and enable people to make changes in the community.

Character education in lower to higher education institutions is continously done and attained. Education institution as a formal institution has an important role in building qualified national character just as the nation founders cited in the regulations. Character education that has been conducted becomes the spirit and motivation for applying education in Indonesia (Koesoema A, 2015: 1).

The research by Damayanti and Wibowo (2016), Widyatmoko and Hudah (2017), Latief and Hasanah (2017), and Kurdi (2019) found that implementation of character education was important for teachers since the key for successful character education lies on the teacher as the role model of character and value education. The problems with the teachers were that there were lack of knowledge and skills, lack of infrastructures, and lack of support from the government and the foundation. Monitor and evaluation from the government and the foundation were also still limited. Another porblem was that teachers understand less about implementation of character education and were lack of synergy and cooperation with students' parents.

YPII that is part of the missionary service of Catholic Church takes part in the missionary by educating teachers personality to be personals with unique character of the Divine's courtesy (Penyelenggaraan Ilahi, PI). YPII tries to formulate its vision and mission 
to fit with the spirituality of Kongregasi Suster-suster Penyelenggaraan Ilahi. The trait of COIS values is attained from two sides: YPII's ideals written in its vision and missions and times that keep changing. The traits are socialized to the teachers and immersed in their personals through students development activites such as Orientation Day for parents and students, regeneration, sex education and gender, recollections, retreats, live in, study tour, extra-curriculer and cocurriculer (Tim Kesiswaan YPI, 2004). The traits are smart, authentic prioritizing on ability to make valuable decisions, communicative with others trully and cooperative that rely on faith to the Divine's courtesy, and solider. They are abbreviated as COIS. It is the core of spirituality of Kongregasi Suster-suster Penyelenggaraan Ilahi that is immersed and shared to every component in YPII educations.

Key success for implementation of trait of COIS values in the schools is teachers. The teachers have had the information about the values through socialisations, internalization during recollections and retreats, and practical trainings in methodology of implementation. Evaluation and monitor on the implementation of COIS were on the Principal's responsibility. Nevertheless, the Principal has not given appropriate proportion for doing them.

In the evaluation conducted by YPII in 2015, it was found through SWOT analysis that the unique values of PI (i.e. COIS) had been formulated well. However, YPII had not yet have the teachers with the profile characterized by COIS. They also had not have guidelines for implementation and thus teachers and students had not embraced and behaved according to COIS (YPII, 2015: 10). According to the testimonies of the Principal and some teachers, teachers did not fully understand the values and how to implement them. It needed process and time to implement the traits but very often teachers did not really realize that the character of COIS values might be important for their personals. Meetings between the Foundation, the Principal, and the team noted that the COIS values were not fully implemented. 
In 2016 a research using questionnaire to the Principals and teachers of YPII Semarang concluded that the values of COIS had been understood but had not been implemented in the teachers personal. The teachers needed a courage to go out their comfort zone and be open to the changes or be active and proactive in facing the changing times, seeing opportunities and taking them using creativity and bright ideas. Every individual has opportunity to grow themselve through their jobs and personal or collective activities for the future (Murwati, 2016).

\section{Basic Concepts in Building Character in Education}

Basic concepts in buildng character in education relate closely to the teacher personal and their role in education. Character of values must be developed in the teacher personal in order to make education to be more meaningful for students.

\section{Teachers and Their Role}

In the Javanese philosophy, a teacher is a person who is listened and patronized. This means that they can be a role model for students and the community regarding to their words and behavior (Wardani, 2010). In the traditional context of Javanese, a teacher is a valued and respected person because they are considered as smart and source of knowledge. Anything said by a teacher, people will abide it. According to Sugeng Bayu Wahyono in Kompas, 11 Juni 2018, such view has been resided deeply in the mind of Indonesians, and this results in obeyed children but less creative ones (Wahyono, 2018).

In the curriculum 2013, such view is changed in which teacher is not a source of knowledge but a facilitator which is able to evolve their talents, intentions, knowledge, and skills. Also, they can grow their spirituality, professionalism, personal maturity, and independence. 
The Law Number 14 Year 2005 about Teacher and Lecturer explains that teacher is a professional educator with their main duties are to educate, teach, mentor, direct, train, assess, and evaluate students in a formal education for early children education, basic education, and middle education. In order to do their job well and be a professional educator, a teacher must plan and do learning process, assesses learning results, does mentoring and training, and does research and community service. In the article 7 , it is stated that professionalism means having talents, intentions, passions, and idealism; committing to increase quality of education, faith, God-fearing, moral; having academic qualification and educational background in the relevant area; having competencies needed in the area of jobs; are responsible for conducting professional job; and taking opportunities to develop their professionalism continuously by studying along their long life.

David Hansen (1995) in his book titled The Call to Teach mentioned that teacher is a call for help to developing other people while developing themselves. Through their jobs, people served will develop in their wholyness and perfection (Suparno, 2004: 9). Thus, it can be concluded that teacher is a professional educator in helping their personal to find and develop the intellectual, emotional, and spiritual potencies to be a persistent personal and a change agent in the community.

In learning process and building character, a teacher has many important roles as follows:

- Teacher as a teacher. They can help and mentor themselves through the learning process so that they can understand clearly what they are studying and become skillful in solving problems. Thus, as a teacher, they need to have particular qualifications such as maturity, good communication, and comfortability with their personal.

- Teacher as an educator. They have responsibility to educate themselves and become the role model. Thus, an educator must have standard and good personal quality in terms of IQ and EQ. 
- Teacher as a facilitator. They have responsibility to facilitate and serve themselves eagerly so that they can easily understand and catch what they are studying. Teacher also grows themselves as a personal with good character.

- Teacher as a director. They have responsibility to always direct themsevels to be able to study and choose correct priority to develop theirselves to become qualified personal.

- Teacher as a motivator. They always motivate themselves so the learning process can be successful and their character develops. In other words, teacher has a role to motivate themselves.

- Teacher as an innovator. They try to interpret past experience and reflect these experience for finding new experience that is more meaningful.

- Teacher as an evaluator. They evaluate themselves and the learning process they conduct.

- Teacher as a call. They help developing others as well as themselves.

With these roles, a professional teacher needs to leverage and develop their competencies in terms of pedagogic, social, personality, and profesionalism. Development of teacher's competencies can be through some ways, such as developing teaching materials, conducting research, making teaching tools, conducting training, etc.

\section{Value Character and Character Building}

Some concepts about value character help in undertanding character building in the personal of teachers. In Greek, character or trait is "charassein" which means a thing to scratch. It is then used to define a cast of an individual character (Adisusilo, 2014: 76-77). Some concepts are explained below.

- Kamus Besar Bahasa Indonesia defines character as character, nature or psychological characteristic, or habit that differentiate an individual from others.

- The Center of Language of the Department of National Education defines character as "gifted, heart, soul, individuality, moral, behavior, personalities, characteristic, attribute, and temperament, characteristic". Thus, an individual with strong character is a person having personality, behavior, characteristic, nature, and character. 
- Zuchdi (2008) noted that character is a set of characteristics signaling goodness, wisdom, and maturity of an individual personal. Character building means inducing values of good accepted by the community is foundation for good and responsible behavior (Adisusilo, 2014: 77).

- Foester (869-1966) defined character as a thing that put an individual in a particular identity. Character can also be defined as a set of values that become habit and characteristics of an individual (Adisusilo, 2014: 77).

- Suparno (2015) mentioned that character can be defined as attitude and positive value of life in an individual that influence way of thinking, behavior, and attitude to others which become their habit (p.29)

- Lickona (2015) stated that character is ownership of values of good in an individual such as honesty, courage, and love. According to Lickona, character has three related parts: moral knowledge, moral feeling, and moral behavior. An individual with good character can know, want, and do good things and those become habit in their way of thinking, in having good heart, and in behaving. These three parts compose maturity of an individual (Lickona, 2015: 84).

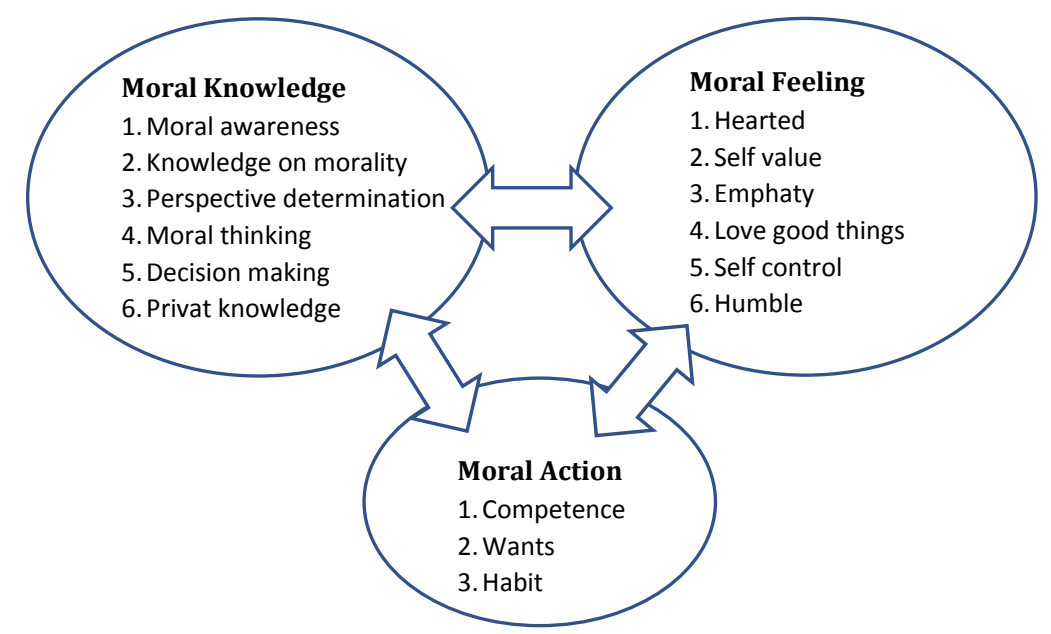

Figure 1. Good character components (adapted from Lickona, 2012:84)

Based on the concepts, it can be stated that character is unique attitude and behavior that are believed as good in an individual and bring positive impacts for others. Every individual has different character and can build personal character as expected. 
Character building is a concious effort intended to developing human wholly through many dimensions they have (religious, moral, personal, social, cultural, temporal, institusional, relasional, etc) for continuously perfecting theirselves in create meaning of life and history in the world with their togetherness with others (Koesoema A, 2019: 55). Every individual can build their personal character through small and simple process (Waruwu, 2010, 130).

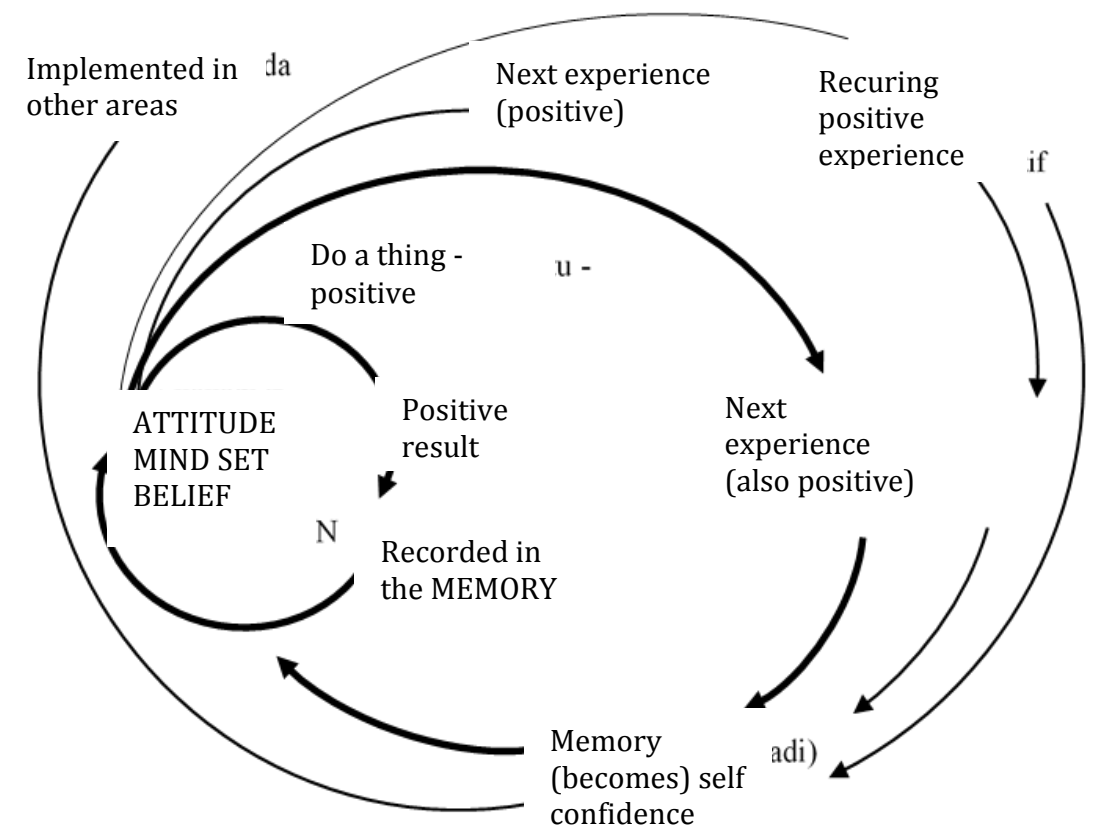

Figure 2. Diagram of character building process (adapted from Waruru, 2010)

\section{METHOD}

The research used qualitative approach and gathered data using Focus Group Discussion (FGD). It evaluated exploratively the implementation of COIS values and the factors support or hinder the implementation. Figure 3 explains the study framework in details.

Uniqueness of PI is implemented through development of students to have personality characterized with smart, authentic, faithful to the Divine's courtesy, and solider (COIS). These characters become the driving spirit in educational process in the class and in mentoring teachers holitistically and continously as stated in the strategic plan of Educational Works of YPII 2015-2025. 


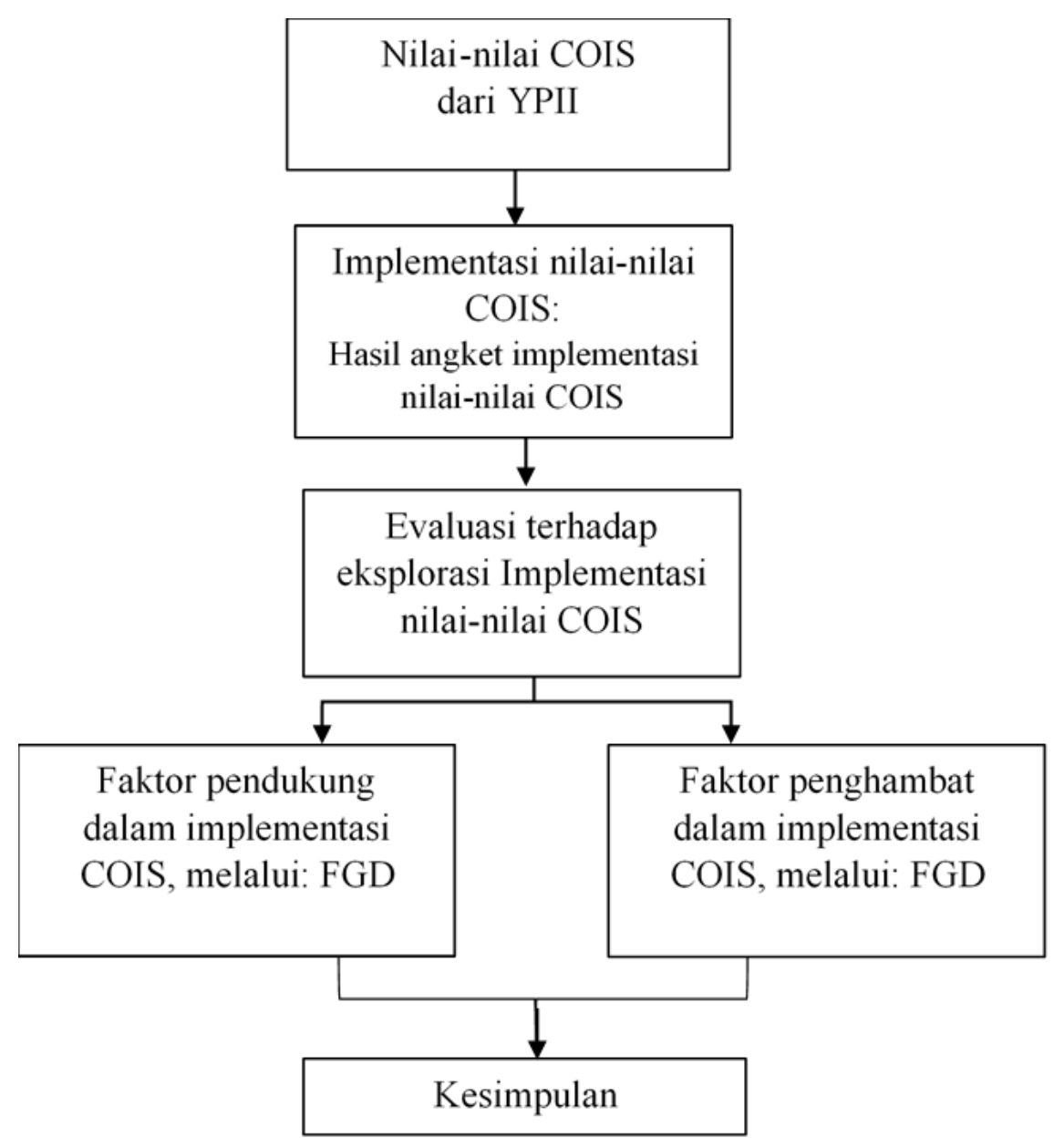

Figure 3. Study Framework

The values of COIS are implemented in the personal of teachers since they are the driver or the central role in education and students mentoring. Exploring the values of COIS in the personal of teachers was conducted through questionnaire on implementation of the values of COIS.

Based on the results from the questionnaire, evaluation on the implementation of the COIS values was then conducted to find supporting and hindering factors in implementing the values using focus group discussion (FGD) to the teachers of YPII Semarang. It then can be concluded to what extent the implementation of COIS values in the personal teachers of YPII Semarang. 


\section{RESULTS AND DISCUSSION}

FGD was conducted in three sessions according to the education level available in YPII: elementary school teachers, junior high school teachers, and senior high school teachers. The FGD covers the following items:

1. Implementation of the COIS values on the teachers

2. Teachers' perception on the COIS values of

3. Characteristics of personal qualifying the COIS values

4. Attaintment of the COIS values to create more meaningful life

5. Factors supported and obstructed the implementation of the COIS values

6. Development of the COIS values in the future (as suggested in the FGD)

The factors supported and hindered the implementation of the COIS values resulted from the FGD are presented in table1.

Table 1. Factors supported and obstructed the implementation of the COIS values

\begin{tabular}{|c|c|}
\hline Supporting Factors & Obstructing Factors \\
\hline The Foundation: & The Foundation: \\
\hline $\begin{array}{l}\text { 1. Guidelines of character of COIS values } \\
\text { formulated by professionals }\end{array}$ & $\begin{array}{l}\text { 1. Guidelines of character of COIS values are still } \\
\text { attained theoretically }\end{array}$ \\
\hline 2. Opportunities for recollections, retreats, and & 2. Lack of intense and continuous mentorings \\
\hline mentoring by professionals & $\begin{array}{l}\text { 3. Lack of intense and continuous programs and } \\
\text { progress monitoring }\end{array}$ \\
\hline The Schools: & The Schools: \\
\hline $\begin{array}{l}\text { 1. Opportunities to reflect in togetherness } \\
\text { 2. Availability of divisions enabling to } \\
\text { implement the COIS values in smaller groups }\end{array}$ & $\begin{array}{l}\text { 1. Discontinuous socialization, wait for the } \\
\text { Foundation } \\
\text { 2. Lack of monitoring and evaluation } \\
\text { 3. Enjoy being in the comfortable situation }\end{array}$ \\
\hline The Teachers: & The Teachers: \\
\hline 1. Open mind and be struggle & 1. Perception that character of COIS values is \\
\hline 2. Self awareness as a role model & on in the society \\
\hline & 2. Less persistent and impatient in the process \\
\hline & 3. Closed personality \\
\hline & $\begin{array}{l}\text { 4. Demand for clear rules and conduct them } \\
\text { firmly }\end{array}$ \\
\hline & $\begin{array}{l}\text { 5. Closed personality, lack of initiatives and } \\
\text { motivations }\end{array}$ \\
\hline
\end{tabular}

Source: FGD, 2019 
The future programs for development of the COIS values are explained in table 2.

Table 2. Future Direction of the Implementation of the COIS Values

\begin{tabular}{|c|c|}
\hline Character & Program \\
\hline COIS & Determine or stress the COIS profile to the teachers of YPII \\
\hline COIS & $\begin{array}{l}\text { Create a cheerful togetherness spirited by the values of COIS - } \\
\text { Gathering must be continuously conducted }\end{array}$ \\
\hline COIS & $\begin{array}{l}\text { Planned, integrated, and continous human resource development } \\
\text { through trainings, such as case-based learnings, project-based } \\
\text { learnings }\end{array}$ \\
\hline \multirow[t]{7}{*}{ Smart } & $\begin{array}{l}\text { Vlogs or comics competitions explaining what smart is and its } \\
\text { indicators. They are open for the Foundation, teachers, and staff, } \\
\text { students in all levels (semester } 1 \text { ) }\end{array}$ \\
\hline & $\begin{array}{l}\text { Competition on giving comment on previous competition that is open } \\
\text { for all civitas on campus (semester } 2 \text { ) }\end{array}$ \\
\hline & Monitor and evaluate the programs (semester 2) \\
\hline & $\begin{array}{l}\text { Follow up the programs of role model. Open for the Foundation, } \\
\text { teachers and staff, and students in all levels (semester } 3 \text { and } 4 \text { ) }\end{array}$ \\
\hline & Monitor and evaluate activities (semester 4) \\
\hline & $\begin{array}{l}\text { Follow up the daily activities conducted by all civitas on campus } \\
\text { (semester } 5 \text { and } 6 \text { ) }\end{array}$ \\
\hline & $\begin{array}{l}\text { Monitor and evaluate the evaluation activities on smart with open } \\
\text { (quote) semester } 6\end{array}$ \\
\hline \multirow[t]{2}{*}{ Authentic } & Know, manage, and explore self potencies \\
\hline & $\begin{array}{l}\text { Follow up daily activities conducted by all civitas on campus - every } \\
\text { end of semester }\end{array}$ \\
\hline \multirow[t]{2}{*}{$\begin{array}{l}\text { Faithful to the } \\
\text { Divine's coustady }\end{array}$} & Build relation with God that enable to develop thankfulness and hope \\
\hline & Mass/prayer/creative contemplation \\
\hline \multirow[t]{2}{*}{ Solider } & Help others or society who are in needed \\
\hline & Develop empathy and care of others on teachers and students \\
\hline
\end{tabular}

\section{CONCLUSIONS AND RECOMMENDATIONS}

\section{Conclusions}

The research found that implementation of the COIS values in the teachers personal of YPII Semarang is not good yet. The reasons are lack of continuous guidance and establishment. Teachers awareness on their role as role model for students is developing.

Based on the evaluation on implementation of the COIS values on the teachres, it can be concluded that:

1. The implementation of the COIS values on the teachers so far results in: 
The values of COIS are the uniqueness of the education exertions of Suster PI. The values have been understood and implemented in the personal teachers of YPII through the process of socialisation, internalisation, and exploration of the values in the teachers. Implementation of the values must be conducted through a gradual process and is monitored and evaluated so that they are developed for their perfection in the future.

Creativity in implementing the values is needed to make their character can immerse well in the teachers personal and make the teachers be more aware of their role as an educator and as a role model for their students.

However, a process is needed to help the teachers in implementing the values of COIS. Even though the values have been displayed in the classes, on the stairs, and other places in the school, they have not made the teachers realized that the values need to be deeply understood.

The Focus Group Discussion (FGD) found that COIS values are implemented in the teachers of YPII Semarang. However, not all teachers implemented them well. The reason is role model. They are aware that they are a role model for students in implementing the values. Role model is one of the effective character building educations.

2. Factors supporting and obstructing the implementation of COIS values on the teachers are as follows:

\section{a. Factors supporting,}

The factors from the Foundation perspective cover (1) the availability of guidance of character of the COIS values formulated by the professional, (2) opportunities for recollection, retreat and mentoring by professionals. From the school perspective: (1) there are situation and chances for gathering during the learning activities and character building, (2) there are divisions that can be the opportunity to implement 
COIS values in small groups. From the teacher perspective: (1) open minded and be strugle, (2) committment on togetherness in every activity, and (3) self awareness as a role model.

b. Factors obstructing:

The factors from the Foundation perspective: (1) the availability of guidelines for character of COIS value are still attained theoritically, (2) lack of clarity in the guidelines, (3) lack of intentisity and continuous mentoring for providing real and simple model for implementation, (4) lack of intensity and continuous program and mentoring progress that seemingly there is no consinuous follow-up. From the school perspective: (1) dicontinuous socialisation, just wait for the Foundation, (2) tend to be passive and no follow- up, (3) lack of creative togetherness, (4) weak monitoring and evaluation, want to stay comfortable, do not want to be busy. From the teacher perspective: (1) Opinion that character of COIS values is not special in the community, (2) Less smart in communication, easily misunderstand, (3) Less persistent and patient in the process, (4) Demand clear rules and be rigid to the rules,(5) Closed personality, lack of initiative and motivation.

\section{Future direction}

It is apparent from the results that COIS values must be the focus and implemented seriously. The implementation may not be at once but gradually. The values must be socialized and implemented to all education components using processes covering (1) integrate the values in the teacher mentoring programs, (2) internalize the COIS values in the personals of YPII education components, (3) explore and familiarize the values in the life through trainings and mentoring with supports and committments of all, the foundation and the schools, (4) give examples or patrons or role model, (5) create situations characterized by COIS values, (6) build school culture characterized by COIS. 


\section{Recommendations}

Referring to the conclusions, recommendations are presented in relation to developing the education and mentoring to young generations in the future.

1. For the education staff and supporting employees, they need to understand and implement COIS values with guidance of the Foundation. This can be done through outbound, gathering, creative competitions for interpreting COIS values.

2. For the teachers, they need to be more open in building their concern for continuously study to understand and implement COIS value in theirselves that in turn spread to the students. New teachers need to continuously understand and implement the COIS values.

3. The management of Yayasan Penyelenggaraan Ilahi Indonesia must keep doing mentoring to the teachers, education staff, and supporting employees through regular and continuous programs. They must also do monitoring and evaluation in order to make the teachers and education components of YPII can be the personals with COIS values characteristic.

4. For the researchers, they can study in-depth and comprehensively internalization of character values to leverage teachers personal. Thus, the teachers can increase teaching quality in their jobs so that the values can be internalized well in building culture in the schools.

\section{REFERENCES}

Darmayanti, S. E., \& Wibowo, U. B. (2016). Evaluasi Program Pendidikan Karakter Di Sekolah Dasar Kabupaten Kulon Progo. Jurnal Prima Edukasia, 2(2), 223. https://doi.org/10.21831/jpe.v2i2.2721

Dryden, G., \& Vos, J. (2000). Revolusi Cara Belajar (The Learning Revolution): Belajar akan Efektif kalau Anda dalam Keadaan "Fun” (I). Bandung: Penerbit Kaifa.

Dwirahayu, G. (2006). Strategi Pembelajaran Eksploratif untuk Meningkatkan Kemampuan Berpikir Matematis (Vol. 62). Jakarta. Retrieved from https://www.researchgate.net/publication/329060677_Strategi_Pembelajaran_Eksplor atif_untuk_Meningkatkan_Kemampuan_Berpikir_Matematis

Koesoema A, D. (2015). Pendidikan Karakter utuh dan menyeluruh. (Erdian, Ed.) (1st ed.). Yogyakarta: PT Kanisius. 
Koesoema A, D. (2019). Pendidikan Karakter Utuh dan Menyeluruh. (Erdian, Ed.) (V). Yogyakarta: PT Kanisius.

Konverensi Waligereja Indonesia. (2016). KITAB HUKUM KANONIK (CODEX IURIS CANONICI). (R. D. R. Rubiyatmoko, Ed.) (Revisi Bah). Jakarta: Konverensi Waligereja Indonesia.

Kurdi, M. S. (2019). Evaluasi Implementasi Desain Pendidikan Karakter Berbasis Pendekatan Humanistik. Elementary: Jurnal Ilmiah Pendidikan Dasar, 4(2), 125. https://doi.org/10.32332/elementary.v4i2.1243

Latief, A. M., \& Hasanah, U. (2017). Evaluasi Terhadap Implementasi Pendidikan Karakter Dengan Sistem Full Day School Pada Madrasahi Btidaiyah Negeri Al Azhar Asy Syarif Indonesia. Prosiding Kolokium Doktor Dan Seminar Hasil Penelitian, 233-246. Retrieved from proceedings.uhamka.ac.id/index.php/psd/article/viewFile/50/46\%0A

Lickona, T. (2015). Educating for Character (Mendidik untuk Membentuk Karakter). (U. Wahyudin, Ed.) (IV). Jakarta: Bumi Aksara.

Murwati. (2016). Implementasi Karakter COIS Pada Guru YPII Kantor Cabang Semarang Universitas Katolik Soegijapranata. Semarang

.Nugroho, A. W. (2016, August 8). Genap 90 tahun Daoed Joesoef. Kompas.Com. Retrieved from

https://nasional.kompas.com/read/2016/08/08/09302201/genap.90.tahun.daoed.joesoe f.bicara.soal.pendidikan.

Presiden Republik Indonesia. (2003). Undang-Undang Republik Indonesia Nomor 20 Tahun 2003 Tentang Sistem Pendidikan Nasional. Produk Hukum, (1), 1-26. https://doi.org/10.1017/CBO9781107415324.004

Suparno, P. (2004). Guru Demokrasi di Era Reformasi Pendidikan. (S. AP, Ed.) (1st ed.). Jakarta: PT Gramedia Widiasarana Indonesia.

Suparno, P. (2015). Pendidikan Karakter di Sekolah Sebuah Pengantar Umum. Yogyakarta: Kanisius.

Sutarjo Adisusilo, J. . (2014). Pembelajaran Nilai-nilai Karakter (3rd ed.). Jakarta: PT Raja Grafindo Persada.

Tarekat Suster-suster Penyelenggaraan Ilahi. (1985). Konstitusi Tarekat Suster-suster Penyelenggaraan Ilahi. Munster: Aschendorffsche Verlagsbuchhandlung GmbH \& Co.

Tim Kesiswaan YPI. (2004). Pedoman Pengembangan Kesiswaan Yayasan Penyelenggaraan Ilahi (1st ed.). Semarang: Yayasan Penyelenggaraan Ilahi.

Wahyono, S. B. (2018, June 11). Ubah Paradigma Pendidikan dalam Budaya. Harian Umum KOMPAS, p. 11.

Wardani, K. (2010). Peran Guru Dalam Pendidikan Karakter Menurut Konsep Pendidikan Ki Hadjar Dewantara, (November), 8-10. 
Waruwu, F. (2010). Membangun Budaya Berbasis Nilai - Panduan Pelatihan bagi Trainer. (G. MC \& C. Subagya, Eds.) (1st ed.). Yogyakarta: Penerbit Kanisius.

Widiyatmoko, F. A., \& Hudah, M. (2017). Evaluasi Implementasi Pendidikan Nilai Dalam Pembelajaran Penjas. Jurnal Ilmiah Penjas, 3(2), 44-60. Retrieved from http://ejournal.utp.ac.id/index.php/JIP/article/view/587

Yayasan Penyelenggaraan Ilahi Indonesia. (2010). Rencana strategi Karya Pendidikan YPII 2010-2013. Semarang: Yayasan Pendidikan Penyelenggaraan Ilahi.

Yayasan Penyelenggaraan Ilahi Indonesia (YPII). (2015). Rencana Strategis 2015-2025, Yayasan Penyelenggaraan Ilahi Indonesia. Semarang: Yayasan Penyelenggaraan Ilahi Indonesia.

YPII. (2017). Pedoman Pengembangan Kesiswaan (2nd ed.). Semarang: Yayasan Pendidikan Penyelenggaraan Ilahi. 